\title{
EVALUATION OF THE ANTICONVULSANT ACTIVITY OF THE ETHANOL LEAF EXTRACT OF UVARIA AFZELLI Sc. Elliot (ANNONAECAE) IN MICE
}

\section{Murtala, Abdullahi Akanji;** ${ }^{2}$ Adesina, A. Omoloye; ${ }^{1}$ Adeyinka, Aderonke Aderinola and}

Olooto, Eniola Wasiu

Department of Pharmacology, Faculty of Basic Medical Sciences, Obafemi Awolowo College of Health Sciences, Olabisi Onabanjo University.

Department of Clinical Pharmacy, Faculty of Pharmacy, Olabisi Onabanjo University.

Department of Chemical Pathology and Immunology, Olabisi Onabanjo University, Ago-Iwoye, Ogun State, Nigeria.

Corresponding Author's e-mail: obj0157@yahoo.com

\section{ABSTRACT} Epilepsy is the fouth most common brain disorder in the world and about 65 million of the global
population are victims. Sadly, the currently available conventional drugs are riddled with numerous side effects, expensive and have not demonstrated adequate capacity in managing this disorder. Hence, the need for safer, cheaper and more effective therapy. This study is aimed at investigating the anticonvulsant activity of the ethanol leaf extract of Uvaria afzelii. Twenty-five (25) mice were
randomly allotted to five different groups of five mice each. The animals were treated orally with 100 , 200 and $400 \mathrm{mg} / \mathrm{kg}$ of the extract respectively and $10 \mathrm{ml} / \mathrm{kg}$ of distilled water. The standard group received diazepam (5 mg/kg, i.m). Both strychnine ( $4 \mathrm{mg} / \mathrm{kg}$, i.p) and picrotoxin ( $5 \mathrm{mg} / \mathrm{kg}$, i.p.) were used to induce convulsion 30 minutes post administration of extract and distilled water, and 15 minutes for standard drug. The onset and duration of convulsion for each mouse were recorded. Mice The extract $(400 \mathrm{mg} / \mathrm{kg})$ significantly $(\mathrm{P}<0.01)$ delayed the onset of convulsion with significant reduction $(\mathrm{P}<0.05)$ in the duration of seizures induced by picrotoxin with $20 \%$ mortality. In the strychnine-induced test $\mathrm{U}$. afzelii $(200 \& 400 \mathrm{mg} / \mathrm{kg}$ ) significantly delayed $(\mathrm{p}<0.001$, 0.0001$)$ the onset of convulsion with mortality of about $40 \%$. Preliminary phytochemical screening revealed the presence of tannins, alkaloids, flavonoids, phenols and saponin. The find
the ethanol leaf extract of Uvaria afzelii possesses anticonvulsant activity.

Keywords: Anticonvulsant, Uvaria afzelii, Diazepam, Strychnine, Picrotoxin .

Accepted Date: 6 April, 2020

Convulsion (seizure) is a symptom of epilepsy, which has been described as the fourth most common serious chronic brain disorder, estimated to affect at least 65 million people in the world, of which 10 million live in Africa alone (WHO, 2019). Epileptic seizures are episodes that can vary from brief and nearly undetectable to long periods of vigorous shaking. In epilepsy, seizures tend to recur, and have no immediate underlying cause while seizures that occur due to a specific cause are not deemed to represent epilepsy (Fisher et al., 2014; Magiorkinis et al., 2010; Fisher et al., 2005). Genetic mutations are linked to a small proportion of the disease (Longo and Dan, 2012). About 80\% of people with epilepsy are living in low and middle income countries and are being affected by gaps in advocacy, diagnosis and treatment (WHO, 2019). The burdens of stigmatization, disability, co- morbidities, poverty and death are even more worrisome and alarming in people living with epilepsy (Solomon et al., 2015). Currently, there are several conventional drugs used to treat this by life threatening side effects which have ultimately defeated their essence. The newe antiepileptic drugs are more effective with fewe adverse effects but they are expensive and this remains a major headache in the treatment of epilepsy especially in Africa. Against this backdrop, researchers are now working hard in areas of plant medicine and related products which are more effective, less expensive and devoid of life threatening adverse effects.

Uvaria afzelii Scott Elliot(Annonaeceae) is found mainly in tropical region (Graham \& Bernard 1978) and has been used traditionally in the treatment of bronchitis and cough (Burkill, 1985). There are different species of Uvaria and they are widely distributed in the tropics, Africa in particular (Graham \& Bernard 1978). U. afzelii is a small tree or spreading shrub growing up to $5 \mathrm{~m}$ tall. The tree is used locally, being harvested from the wild for food and medicines. It is widely distributed and grown in the Southern part of Nigeria, where it is known by various local names such as "gbogbonishe" (Yoruba), "Umimiofia" (Igbo) and "Osu-umimi" (Ukwani) "Odugbeni, 2008) Lolly it is used in the trethen (Ocugbent of cough, vaginal tumo and feet, diabetes and gonorrhea (Kayode et al., 2009).The flowers are very heavily scented. The bark or pieces of the stem are sometimes put into palmwine to add potency, or are added to the distillate to give colour to the spirit (Burkil, 1985). All the parts of the plant are fragrant and as such are used in the preparation of pomade in Ghana. Investigations have revealed its bacteriocidal activity against Grampositive and acid-fast bacteria (Lawal and Okoli, 2011). Other species of Uvaria have been found useful in folklore medicine. This includes $U$. doeringii- the leaf decoction is used for piles, palpitations and pains (Burkill, 1985). U.scabrida is used in the treatment of insanity while $U$. thomasii is used in the form of a leaf decoction for catarrh and colic (Kerharo \& Adam 1974). U. tortilis is used in the treatment of amenorrhoea (Borquet \& Debray, 1974). Preliminary ethnobotanical survey conducted on U. afzelii revealed its use in the treatment CNS disorders including epilepsy. The aim of this study is to investigate the anticonvulsant activity of the ethanol leaf extract of $U$. afzelli which to the best of our knowledge is yet to be reported.

\section{MATERIALS AND METHODS}

Plant collection

Fresh leaves of $U$. afzelii were collected from the environs of Ijebu North-East local Government area of Ogun state, South-west, Nigeria Identification and authentica Pharmartment of acy, Olabisi Onabanjo University, Ago I Woye, Ogun State, Nigeria.

\section{Extraction}

The fresh leaves of $U$. afzelii were air-dried, grinded, weighed and soaked in $1.5 \mathrm{~L}$ of ethanol for 48 hours and were filtered. The filtrates were evaporated to dryness at $40^{\circ} \mathrm{C}$ under reduced pressure to give a dark brown extract. The dried extract was weighed and dissolved in distilled water to give a desirable working concentration before administration to experimented animals

\section{Experimented animals}

Albino mice (20-30g) of both sexes used in this study were obtained from the animal house, Faculty of Pharmacy, Olabisi Onabanjo University, Ago lwoye, Nigeria. The animals were kept in well-ventilated hygienic polycyclic cages $(38 \mathrm{~cm} \times 23 \mathrm{~cm} \times 10 \mathrm{~cm})$ and maintained under standard environmenta conditions (Temperature $25 \pm 6^{\circ} \mathrm{C}$ ). They were allowed free access to standard dry pellet diet and water ad libitum. The mice were acclimatized for 14 days before the commencement of the experiment. Experimental procedures were carried out in Experime Laborator of Healts Gu National Institute for Health Publications, 1985).

\section{Preliminary Phytochemical Screening}

Preliminary phytochemical screening to detect the presence or absence of saponin, flavonoids, alkaloids, phenols, tannins was carried out according to the procedures of Sofowora and Odebiyi,(1978).

\section{PHARMACOLOGICALSTUDIES}

Picrotoxin-Induced Seizures Test

Picrotoxin $(5 \mathrm{mg} / \mathrm{kg}, i . p$. $)$ was administered to the mice $30 \mathrm{~min}$. after treatment with distilled wate $(10 \mathrm{ml} / \mathrm{kg}, \mathrm{p}$.$) and extract (100,200$ and $400 \mathrm{mg} / \mathrm{kg}$ bodyweight), and $15 \mathrm{~min}$ (100, 200 and $400 \mathrm{mg} / \mathrm{kg}$ i.m). The onset and duration of convulsion for eac mouse were recorded for $30 \mathrm{~min}$ after the administration of picrotoxin (Malami et al., 2016, Murtala and Akindele, 2018)

Strychnine-induced seizures test

Strychnine $(4 \mathrm{mg} / \mathrm{kg}$,i.m. $)$ was administered to the mice 30 min. after treatment with distilled water (10 $\mathrm{ml} / \mathrm{kg}$, p.o) and extract (100, 200 and $400 \mathrm{mg} / \mathrm{kg}$ bodyweight), and $15 \mathrm{~min}$. after diazepam ( $2 \mathrm{mg} / \mathrm{kg}$ i.m). The onset and duration of convulsion for each mouse were recorded for $30 \mathrm{~min}$ after the administration of strych fine (Porter et al., 1984; Perazzo et al., 2003, Gao et al., 2018).

\section{Statistical analysis:}

Results obtained were expressed as mean $\pm \operatorname{SEM}(\mathrm{n}=$ 5 ). The data were analyzed using one way ANOVA followed by Dunnett's post-hoc test using Graph Pad 
Prism 6 Software. Results were considered significant when $P<0.05$.

\section{RESULTS}

Preliminary Phytochemical Screening

Preliminary phytochemical screening showed the presence of tannins, saponin, phenol, alkaloids, flavonoids and cardiac glycosides in the extract.

\section{Pharmacological studies}

Picrotoxin-induced seizure

The extract 100, 200 and $400 \mathrm{mg} / \mathrm{kg}$ produced a dose dependent increase in seizure latency. The maximum effect of the extract was seen at $400 \mathrm{mg} / \mathrm{kg}$ with $19.86+1.50$ min 19.86 \pm 1.50 min seizure latency, which was significantly $(\mathrm{P}<0.01)$ greater than $3.58 \pm 0.41 \mathrm{~min}$ seizure latency observed with the control. On the duration of the seizure, at $100 \mathrm{mg} / \mathrm{kg}$, the extract narrowly increased the duration of seizure which was not significant compared with the control. However at $400 \mathrm{mg} / \mathrm{kg}$, the extract, $1.60 \pm 0.244 \mathrm{~min}$

Table 1. Effects of the Ethanol Leaf Extract of $U$. afzelli in picrotoxin-induced seizure test

\section{in mice}

\begin{tabular}{llllll}
\hline Treatment & $\begin{array}{l}\text { Dose } \\
(\mathrm{mg} / \mathrm{kg})\end{array}$ & $\begin{array}{l}\text { Onset of seizure } \\
(\mathrm{min})\end{array}$ & $\begin{array}{l}\text { Duration of } \\
\text { seizure (min.) }\end{array}$ & $\begin{array}{l}\text { Convulsion } \\
\text { ratio }\end{array}$ & $\begin{array}{l}\text { Mortality } \\
\text { ratio }\end{array}$ \\
\hline Control & $10 \mathrm{ml} / \mathrm{kg}$ & $3.58 \pm 0.41$ & $4.97 \pm 1.09$ & $5 / 5$ & $5 / 5$ \\
Diazepam & 5 & $22.96 \pm 1.35^{* * *}$ & $1.16 \pm 0.63^{*}$ & $3 / 5$ & $0 / 5$ \\
Extract & 100 & $5.62 \pm 0.71$ & $6.31 \pm 0.70$ & $5 / 5$ & $3 / 5$ \\
Extract & 200 & $15.22 \pm 6.17^{*}$ & $2.05 \pm 0.92^{*}$ & $5 / 5$ & $2 / 5$ \\
Extract & 400 & $19.86 \pm 1.50^{* *}$ & $1.60 \pm 0.24^{*}$ & $5 / 5$ & $2 / 5$
\end{tabular}

Values represent mean \pm S.E.M. $(\mathrm{n}=5){ }^{*} \mathrm{P}<0.05,{ }^{* *} \mathrm{P}<0.01,{ }^{* * *} \mathrm{P}<0.001$ vs. Control (One way

ANOVA followed by Dunnet's multiple comparison test)

Table2: Effects of the Ethanol Leaf Extract of $U$. afzelli in strychnine-induced seizure test in mice

\begin{tabular}{llllll}
\hline Treatment & $\begin{array}{l}\text { Dose } \\
(\mathrm{mg} / \mathrm{kg})\end{array}$ & $\begin{array}{l}\text { Onset of seizure } \\
\text { (min.) }\end{array}$ & $\begin{array}{l}\text { Duration of } \\
\text { seizure (min.) }\end{array}$ & $\begin{array}{l}\text { Convulsion } \\
\text { ratio }\end{array}$ & $\begin{array}{l}\text { Mortality } \\
\text { ratio }\end{array}$ \\
\hline Control & $10 \mathrm{ml} / \mathrm{kg}$ & $0.454 \pm 0.029$ & $1.144 \pm 0.1695$ & $5 / 5$ & $5 / 5$ \\
Diazepam & 5 & $23.20 \pm 2.596^{* * * *}$ & $0.694 \pm 0.1809$ & $4 / 5$ & $1 / 5$ \\
Extract & 100 & $6.800 \pm 1.356$ & $2.498 \pm 1.657$ & $5 / 5$ & $3 / 5$ \\
Extract & 200 & $12.40 \pm 1.806^{* * *}$ & $1.210 \pm 0.5016$ & $5 / 5$ & $3 / 5$ \\
Extract & 400 & $15.40 \pm 1.720^{* * * *}$ & $0.460 \pm 0.1043$ & $5 / 5$ & $2 / 5$ \\
\hline
\end{tabular}

Values represent mean \pm S.E.M. $(\mathrm{n}=5)^{*} \mathrm{P}<0.05,{ }^{* *} \mathrm{P}<0.01,{ }^{* * *} \mathrm{P}<0.001,{ }^{* * *} \mathrm{P}<0.0001$ vs. Control (One way ANOVA followed by Dunnet's multiple comparison test)

\section{DISCUSSIONAND CONCLUSION}

DISCUSSION

Essentially, the concept of traditional medicine is gaining more popularity in Africa and even beyond the shores of the continent. The usefulness of these medicinal plant materials is largely due to their phytochemical components or multitude of secondary metabolites present in these plants (Akinmoladun et al., 2007). The preliminary phytochemical screening of the leaf extract of $U$. Afzelii revealed the presence of tannins, alkaloids, saponin, phenol, flavonoids and cardiac glycosides, as previously reported by Sofowara, 1993, Trease and Evans, 1989, Yadav and Agarwala, 2011. These secondary metabolites, singly or in combination, account for some of the pharmacological effects credited to this plant. In this study, it was found that the extracts at 400 $\mathrm{mg} / \mathrm{kg}$, significantly increased seizure latency and reduced the duration of seizure in Picrotoxininduced convulsion test. In strychnine-induced convulsion test, the exract at 200 and $400 \mathrm{mg} / \mathrm{kg}$ significantly increased the onset of convulsion but did not affect the length of convulsion. Picrotoxin, a GABA antagonist, was reported to cause convulsion by antagonizing $\mathrm{GABA}_{\mathrm{A}}$ receptorlinked chloride ion channels thereby blocking the influx of chloride ions into the brain cells (Leonard, 2000, Nicoll, 2001). Picrotoxin has also been reported to block glycinergic activity. Strychnine, a competitive glycine antagonist, an inhibitory amino acid and neurotransmitter has been reported also to cause convulsion (Ishola et al., 2013). The seemingly blocking effects of plant extracts on the actions of picrotoxin and strychnine suggest that the plant may have delayed seizure latency and reduced duration of convulsion by affecting the GABAergic mechanisms and glycinergic pathways respectively (Mora-Perez et al., 2016, Murtala and Akindele 2018, Shelar et al., 2018). Based on these findings, $U$. afzelii can be said to possess anticonvulsant activity since it increases the seizure latency and decreases its duration. Ayoka et al., (2006), reported phenolic compounds, especially flavonoids to exhibit a wide range of neuropharmacological properties such as sedative, anticonvulsant and antipsychotic activities.
Murtala and Akindele (2018) reported the involvement of steroids, saponins and alkaloids in the anticonvulsant activity of hydroethanol leaf extract of Newbouldia laevis. The anticonvulsant activities of steroids and terpenoids have also been reported in the methanolic stem and root extracts of Katanchoe pinnata (Mora-Perez et al., 2016). The flavonoids, steroids, saponins and alkaloids present in $U$. afzelii may be responsible for its anticonvulsant activity. However, the involvemen of other secondary metabolites in the plant cannot be ruled out (Sowemimo et al., 2012).

\section{CONCLUSION}

The findings in this study have shown that the ethanol leaf extract of Uvaria afzelii possesses anticonvulsant activity and this justifies the use of the leaf of Uvaria afzelii in the treatment of convulsion in traditional medicine. However, there is need for more work to be done to ascertain the actual components involved and the possible mechanism of action.

\section{REFFRENCES}

Akinmoladun A.C., Ibukun E.O., Afor E., Obutor E.M. and Farounbi E.O. (2007).

Phytochemical constituent and antioxidant activity of extract from leaves of Ocinum gratissinum. Scientific Research and Essay, 2: 163-166

Ayoka A. O, Akomolafe R. O, Iwalewa E. O, Akanmu M. A. and Ukpomwan O. E. (2006) Sedative, antiepileptic and antipsychotic effects of Spondias monbin (Anacardiaceae) in mice and rats. $J$ Ethnopharmacol, 103:166-175.

Borquet and Debray. (1974) Evaluation of plant medicine of the Ivory coast. trau. doc.orstom. seru 310-321.

Burkill H. R. M. (1985). The useful plants of west tropical Africa, vol. 1 royal botanic gardens, kew, UK.

Fisher R. S, Van Emde Boas W. and Blume W. (2005) Epileptic seizures and epilepsy. Definitions proposed by the international league against epilepsy (ILAE) and the international bureau for epilepsy (IBE). Epilepsia; 46: 470-472. 
Fisher S. A, Van Jaarsveld C. H. M, Liewellyn C. H. and Wardle J. (2014) Genetic and environmental influences on infant sleep. Pediatrics; 129:1091-1096.

Gao, M, Sato, M and Ikegaya, Y. (2018). Machine Learning-based Prediction of SeizureInducing Action as an Adverse Drug Effect. Yakugaku Zasshi, 138 (6): 809-813.

Graham, B and Bernard, D. (1978). The flowering plants of the world hey wood, international projects ltd., Oxford, 138 (6): 809-813.

Ishola O.I., Sunday O.O., Omoniyi K.Y. and Ngozi K.E. (2013). Mechanism of anticonvulsant and sedative ations of the Ethanolic Stem-bark Extract of Ficus sur Forssk (Moraceae) in Rodents. Pakistani Jounal of Biological Sciences, 16 (21):

$$
\text { 1287-1294 }
$$

Kayode J, Ige O.E, Adetogo T.A. and Igbakin A.P. (2009). Conservation and biodiversity. Survey of plant barks used in the native pharmaceutical extraction in Akoko region. Ethnobotanical Leaflets, 13: 665-67.

Kerharo J. and Adam J. G. (1974). Pharmacopee senegalaise traditionnelle: Plantes medicinales et toxique. Vigots Fre res, paris, 575-576.

Larson M. D (1969). An analysis of the action of strychnine on the recurrent IPSP and amino acid induced inhibitions in the cat spinal cord. Brain Research, 15: 185-200.

Lawal T. O. and Okoli A. S. (2011). Evaluation of extracts of Anthocleistadja lonensis, nauclea latifolia and Uvaria afzelii for activity against bacteria isolates from nongonococcal urethritis. J. Ethnopharmacol, 14: 17-21.

Leonard B. E (2003). Fundamentals of Psychopharmacology, $3^{\text {nd }}$ Edition, Chichester: John Wiley and Sons. ISBN: 970-0471-52178-5.

Magiorkinis G., Vana S. Emmanouil M., Dimitrios P., Antigoni K., Robert B., Christipher F., Oliver G. P. and Angelos H. (2013). Integrating phytodynamics and epidemiology to estimate transmission diversity in viral epidemics. PLOS Computational. Biology 9(1): e1002876.

Malami, S, Kyari, H, Danjuma, N. M, Yau, J and Hussaini, I. M. (2016). Anticonvulsant properties of methanol leaf extract of
Laggera aurita Linn. F. (Asteraceae) in laboratory animals Journal of Ethnopharmacology, 191:301-306

Mora-Perez A., Adel M. and Hernandez-Medel R. (2016). Anticonvulsant activity of methanolic extract from Katanchoe pinnata (Lam.) stems and roots in mice: A comparison to diazepam. Neurologia, 31 (3): 161-168

Murtala A.A. and Akindele A.J. (2018). Anticonvulsant, muscle relaxant and invitro antioxidant activities of hydroethanol leaf extract of Newbouldia laevis Seem. (Bignoniaceae) in mice. UNILAG Journal of Sciences, 6 (11): 38-45.

Nicoll, R.A. (2001). Introduction to Pharmacology oc CNS Drugs. In: Basic and Clinical Pharmacology, Katzung, B.G. (Ed.). $8^{\text {th }}$ Edn. Lange Medical Books/McGraw-Hill, New York, USA. 351-363

Odugbemi T. A (2008). Outlines and pictures of medicinal plants from Nigeria. University of Lagos Press, Lagos, Nigeria. 102

Perazzo F. F, Carvalho J. C, Carvalho J. E, Rehder V. L. (2003). Central properties of the essential oil and the crude ethanol extract from aerial parts of Artemisia аппиа L. Pharmacology Research, 48: 497-502.

Porter R. J, Cereghino J. J, Gladding G. D, Hessie B. J, Kupferberg H. J, Scoville B, White B. G. (1984). Antiepileptic Drug Development Program. Cleve Clinical $Q$ 51:293-305.

Shelar M.K., Patil M.J. and Chaudhari R.B. (2018). Evaluation of anticonvulsant activity of ethanolic extracts from leaves of Excoecaria agallocha. Future Journal of Pharmaceutical Sciences, 4: 215-219

Sofowora A. E. and Odebiyi A. (1978) Phytochemical screening of Nigerian medicinal plants. Lloydia 41(3): 234-246.

Sofowora, A. (1993) Medicinal plant and Traditional Medicine in Africa. 2nd Edition, John Wiley and sons, New York, USA, 6-65.
Solomon L.M., Emilo P., Philippe R. and Torbjom T. (2015). Epilepsy: New advances. The Lancet, 385 (9971): 884-898

Sowemimo A, Odunlami O, Fageyinbo M. (2012). Anticonvulsant activities of Hedranthera barteri (Apocynaceae) in mice. Journal of pharmaceutical biology, 50 (7): 828-831

Trease G.E. and W.C. Evans. (1989) Trease and Evans Textbook of pharmacognosy. 13th Edition, Cambridge University Press, London, 546.
United States National Institute for Health Publications, 1985.

World Health Organization, (2019). Epilepsy: A public health imperative. Neurology and public health; WHO report, ISBN: 978-92-4-151593-1

Yadav R.N.S and Agarwala M. (2011) Phytochemical analysis of some medicinal plants. Journal of phytology, 3 (12):10-14 